\title{
Haematology and serum profile of rabbits due to generation interval, housing systems and sex
}

Ayo-Ajasa ${ }^{1}$,O. Y., Aina ${ }^{1}$ A. B. J., Sowande ${ }^{1}$ O. S., Egbeyale ${ }^{1}$ L.T., Ozoje ${ }^{2}$ M. O.,Agaviezor ${ }^{3}$ B. O. and Abel, F. A. S

${ }^{1}$ Department of Animal Production and Health, Federal University of Agriculture, Abeokuta. ${ }^{2}$ Department of Animal Breeding and Genetics, Federal University of Agriculture, Abeokuta. ${ }^{3}$ Department of Animal Science and Fisheries, University of Port Harcourt, Port Harcourt. ${ }^{4}$ Federal Institute of Industrial Research, Oshodi (FIIFO), Lagos Corresponding author e-mail:olapejuyemisi@yahoo.com

\begin{abstract}
A total of ninety-six (96) weaner rabbits (Chinchilla and New Zealand White crossbred) were used for this study and were divided into forty-eight (48) per generation. These fortyeight weaner rabbits were further divided into three replicates of four males (12) and four females each (12) housed in cage (24) and deep litter system (24).This experiment was carried out for two generations to determine the effect of generation interval, housing systems and sex on the haematological and serum profile of rabbits. Data obtained were analyzed using Analysis of Variance test in a 2x2x2 factorial arrangement. The study showed that Packed cell volume (PCV), red blood cells (RBC) and haemoglobin (HB) were not significant in both generations while higher significant $(p<0.05)$ values of albumin were observed in first generation and white blood cells (WBC), globulin, aspartate amino transferase (AST) and alanine amino transferase (ALT) were significantly higher in the second generation. Sex had no significant $(p>0.05)$ effect on most of the biochemical parameters studied except for RBC and glucose which had $4.12 \times 10^{12} / \mathrm{L}$ and $69.23 \mathrm{mg} / \mathrm{dl}$, for males and $3.68 \times 10^{12} / \mathrm{L}$ and $78.78 \mathrm{mg} /$ dl for females, respectively in the second generation. In addition, the AST and ALT values were also higher in the females than in the males in the first generation but with no significant ( $p>0.05$ ) difference. Housing system result showed that $\operatorname{WBC}\left(6.29 \times 10^{9} / \mathrm{L}\right)$ and glucose $(78.35 \mathrm{mg} / \mathrm{dl})$ of rabbits were significantly $(p<0.05)$ increased in the cage and deep litter system, respectively in the first generation while total serum protein, albumin and globulin were significantly $(p<0.05)$ higher in rabbits housed in the deep litter system in the second generation. Higher values were recorded for AST and ALT in the deep litter system than the cage system in both generations except that the values of ALT were within the same range for both housing systems in the second generation. This study clearly indicated that both housing systems support rabbit production without any negative influence on the immune status of the rabbit.
\end{abstract}

Key words: Rabbit, Sex, Haematology, Generation, Cage, Deep litter.

\section{Introduction}

Haematological indices are an index and a reflection of the status of the blood available for an animal to meet its physiological, biochemical and metabolic necessities (Ewuolaet al, 2004). Blood examination gives the opportunity to investigate the presence of several metabolites and other constituents and helps detect conditions of stress, which can be nutritional, environmental or physical (Aderemi, 2004). 


\section{Introduction}

Haematological indices are an index and a reflection of the status of the blood available for an animal to meet its physiological, biochemical and metabolic necessities (Ewuolaet al, 2004). Blood examination gives the opportunity to investigate the presence of several metabolites and other constituents and helps detect conditions of stress, which can be nutritional, environmental or physical (Aderemi, 2004). Although there are a lot of studies on blood parameters of various domestic animals, few data are available about hematological values of farm rabbits in response to different housing systems. The increasing popularity in rabbit rearing has been seen as a reason for the increasing demand for veterinary services to treat rabbits. It is therefore important to have available and reliable set of normal haematological and biochemical reference values to aid in the diagnosis and prognosis of rabbit diseases. Most of the normal reference values quoted in the literature were derived from rabbits reared under temperate conditions.

Cazabonet al. (2000) reported on haematological values in rabbits reared at a single rabbitry in Trinidad. These rabbits were, however, reared under conditions that are different from those that are reared under tropical climate. It was therefore important to carry out this study in order to obtain more reliable estimates for haematological parameters as well as serum chemistry values of rabbits reared in two different housing systems for two generations.

\section{Materials and Methods}

The research was carried out at the Rabbitary Unit of the University of Agriculture Teaching and Research Farm, Alabata road, Abeokuta, Nigeria $\left(7^{0} 10^{\prime} \mathrm{N}\right.$ and $\left.3^{\circ} 2^{\prime} \mathrm{E}\right)$. The area lies in the South West part of Nigeria and has a prevailing tropical climate with a mean annual rainfall of about $1037 \mathrm{~mm}$. The mean ambient temperature ranges from $28^{\circ} \mathrm{C}$ in December to $36^{\circ} \mathrm{C}$ in February with a yearly average of $34^{\circ} \mathrm{C}$. The Relative humidity ranges from $60 \%$ in January to $94 \%$ in August with a yearly average of about $82 \%$ (Google Earth, 2014). The vegetation represents an interphase between the tropical rainforest and derived savannah. A total of forty-eight, eight weeks old weaner rabbits (Chinchilla and New Zealand White crossbred), were divided equally into; cage and deep litter systems. Each system consisted of three replicates of four males each and three replicates of four females each. The experimental design used was a $2 \times 2 \times 2$ factorial arrangement in a complete randomized design, and the factors were generations, housing systems, and sex, respectively. The experiment was carried out for two generations (years). All the routine and occasional management practices were carried out as and when due throughout each generation. The does were mated at maturity with a mating ratio of 1:4. The does were hand mated in the morning and in the evening; the bucks were allowed to ride 3- 4 times before they were withdrawn.

Pregnancy test was carried out on the does by palpating on the $14^{\text {th }}$ and $20^{\text {th }}$ day. A clean and well-disinfected kindling box was provided for the does to make nest of fur in preparation for birth. The rabbits were identified by their coat colors and weighed one week after birth using hand gloves to handle the kits. After weaning at 8 weeks, the young rabbits were fed daily and supplied with water ad libitum. Forty-eight weaner rabbits from the litters obtained in the first generation were used to carry out the experiment in the second generation. At 
the end of the experimental period, blood samples were collected from two randomly selected rabbits per treatment group. About $5 \mathrm{ml}$ of blood were collected from the external ear vein with a sterilized disposable syringe and needle. The blood was immediately transferred into well labeled tubes with ethylene diamine-tetraacetic acid (EDTA) $(0.05 \mathrm{ml})$ as anticoagulant, while the tubes containing blood samples were kept in ice containers. Haematological analysis was carried out within 3 hours of blood collection. The parameters determined were packed cell volume (PCV), red blood cell (RBC) counts, white blood cell (WBC) counts, haemoglobin $(\mathrm{Hb})$, glucose, total serum protein (TSP), albumin, globulin, creatinine, aspartate amino transferase (AST), Alanine amino transferase (ALT) concentration following standard procedures described by Davice and Lewis (1991). Data obtained from this study were subjected to analysis of variance (ANOVA) techniques using least squares (SAS, 1999). In case of significant effects, means were separated and compared by the Duncan Multiple Range Test at 5\% level of probability (Duncan, 1955).

\section{Results}

Table 1 shows the result of the effect of generation on the haematology and serum profile of the rabbits. The result revealed that the values of PCV, RBC and haemoglobin were similar in both generations while a significantly $(\mathrm{p}<0.05)$ higher effect was observed in WBC in the second generation. The values of serum glucose, protein and creatinine increased in the second generation with no significant ( $>0.05)$ differences. However, serum albumin and globulin were significantly $(p<0.05)$ higher in the first and second generation respectively, while aspartate amino transferase (AST) and alanine amino transferase (ALT) were significantly $(p<0.05)$ higher in the second generation.

Table 2 presents the effect of the system of housing on the haematology and serum profile of the rabbits in the first generation. Higher but not significantly $(\mathrm{p}>0.05)$ different values were recorded for $\mathrm{PCV}, \mathrm{Hb}$ and $\mathrm{RBC}$ in the rabbits housed in the deep litter system while glucose value was significantly $(\mathrm{p}<0.05)$ higher in the same system. However, a significantly $(\mathrm{p}<0.05)$ higher value was recorded for $\mathrm{WBC}$ in the cage system. Higher $(p>0.05)$ values were recorded for albumin, AST and ALT in the deep litter system than the cage system.

Table 3 shows the effect of the system of housing on the haematology and serum profile of the rabbits in the second generation. The total protein, albumin and globulin values were significantly $(p<0.05)$ higher in the deep litter system compared to the cage system. Other parameters followed the same trend of higher but not significantly different values in the deep litter system except for the WBC which recorded a higher but not significantly different value in the cage system.

The effect of sex on the haematology and serum parameters of the rabbit in the first generation is presented in Table 4. All the measured parameters were not influenced $(\mathrm{P}>0.05)$ by sex.

The effect of sex on the haematology and serum parameters of the rabbit in the second generation is presented in Table 5. Red blood cell and glucose were the parameters that were influenced $(\mathrm{P}<0.05)$ while other measured indices were similar $(\mathrm{P}>0.05)$. The $\mathrm{RBC}$ value $\left(4.12 \times 10^{12} / \mathrm{L}\right)$ in male rabbit was higher than their female counterparts $\left(3.68 \times 10^{12} / \mathrm{L}\right)$ while the glucose in female $(78.78 \mathrm{mg} / \mathrm{dl})$ was more $(\mathrm{P}<0.05)$ than the value $(69.23 \mathrm{mgl}-1)$ obtained in male. 
Table 1: Effect of generation on haematology and serum profile of rabbits

\begin{tabular}{llll}
\hline & \multicolumn{2}{l}{ Generation } & \\
\cline { 2 - 3 } Parameters & 1 & 2 & SEM \\
\hline Packed Cell Volume $(\%)$ & 31.38 & 33.38 & 1.03 \\
Haemoglobin $(\mathrm{g} / \mathrm{dl})$ & 10.44 & 11.25 & 0.38 \\
White Blood Cell $\left(\mathrm{x} 10^{9} / \mathrm{L}\right)$ & $5.59^{\mathrm{b}}$ & $7.41^{\mathrm{a}}$ & 2.29 \\
Red Blood Cell $\left(\mathrm{x} 10^{12} / \mathrm{L}\right)$ & 3.71 & 3.90 & 0.14 \\
Glucose $(\mathrm{mg} / \mathrm{dl})$ & 71.99 & 74.00 & 2.37 \\
Total serum protein $\left(\mathrm{gl}^{-1}\right)$ & 58.30 & 61.33 & 1.18 \\
Albumin $\left(\mathrm{gl}^{-1}\right)$ & $37.79^{\mathrm{a}}$ & $34.04^{\mathrm{b}}$ & 0.93 \\
Globulin $\left(\mathrm{gl}^{-1}\right)$ & $20.11^{\mathrm{b}}$ & $27.29^{\mathrm{a}}$ & 1.18 \\
Creatinine $\left(\mathrm{mgdl}^{-1}\right)$ & 0.86 & 0.99 & 0.06 \\
AST $(\mathrm{U} / \mathrm{L})$ & $16.75^{\mathrm{b}}$ & $23.25^{\mathrm{a}}$ & 1.07 \\
ALT $(\mathrm{U} / \mathrm{L})$ & $12.21^{\mathrm{b}}$ & $15.63^{\mathrm{a}}$ & 0.93 \\
\hline
\end{tabular}

$\mathrm{a}, \mathrm{b}$ : Means on the same row with different superscripts are significantly different at $(\mathrm{p}<0.05)$ AST- Aspartate amino transferase

ALT- Alanine amino transferase

Table 2: Effect of housing system on the haematology and serum profile of rabbits in first generation

\begin{tabular}{|c|c|c|c|}
\hline \multirow[b]{2}{*}{ Parameters } & \multicolumn{2}{|c|}{ System } & \multirow{2}{*}{ SEM } \\
\hline & Cage & Deep I & \\
\hline Packed Cell Volume (\%) & 30.50 & 32.25 & 1.68 \\
\hline Haemoglobin $(\mathrm{g} / \mathrm{dl})$ & 10.00 & 10.88 & 0.75 \\
\hline White Blood Cell $\left(\times 10^{9} / \mathrm{L}\right)$ & $6.29^{\mathrm{a}}$ & $4.90^{\mathrm{b}}$ & 2.55 \\
\hline Red Blood Cell (x10 $12 / \mathrm{L})$ & 3.63 & 3.80 & 0.27 \\
\hline Glucose $(\mathrm{mg} / \mathrm{dl})$ & $65.63^{\mathrm{b}}$ & $78.35^{\mathrm{a}}$ & 4.01 \\
\hline Total serum protein $\left(\mathrm{gl}^{-1}\right)$ & 58.73 & 57.87 & 1.90 \\
\hline Albumin $\left(\mathrm{gl}^{-1}\right)$ & 37.68 & 37.90 & 1.90 \\
\hline Globulin $\left(\mathrm{gl}^{-1}\right)$ & 20.22 & 20.00 & 2.10 \\
\hline Creatinine $\left(\mathrm{mgdl}^{-1}\right)$ & 0.90 & 0.83 & 0.09 \\
\hline AST (U/L) & 15.17 & 18.33 & 1.90 \\
\hline ALT (U/L) & 11.17 & 13.25 & 1.02 \\
\hline
\end{tabular}

a, $b$ : Means on the same row with different superscripts are significantly different at $(p<0.05)$

AST- Aspartate amino transferase

ALT- Alanine amino transferase 
Table 6 shows the interaction effect between generation and housing system on the haematological and serum chemistry of the rabbits. The result showed that out of all the parameters measured, only WBC and total serum protein were significantly $(p<0.05)$ affected. WBC was significantly $(p<0.05)$ higher in the two housing systems in the second generation. The total serum protein was highest $(\mathrm{P}<0.05)$ on deep litter in the second generation while the least value $\left(53.38 \mathrm{gl}^{-1}\right)$ was from cage housing system in the same generation but the values in the first generation were similar $(\mathrm{P}>0.05)$. $\mathrm{PCV}$, haemoglobin and $\mathrm{RBC}$ ranged from 30.50 to $33.75 \%, 10.00$ to $11.35 \mathrm{gl}^{-1}$ and 3.63 to $3.95 \times 10^{12} / \mathrm{L}$, respectively. The result of the interaction effects between generation and sex is shown in Table 7. The results showed that there was no interaction $(\mathrm{P}>0.05)$ between the two factors on haematological and serum profile of the rabbits. The WBC ranged from 3.68 to $4.12 \times 10^{12} / \mathrm{L}$. Haemoglobin values were the same in both sexes in the second generation. There was an increase in RBC in the males in the second generation while the females had the same value for both generations. Serum glucose and globulin were also increased in both sexes in the second generation, but the highest values were observed in the females. The same trend was observed for the transaminase enzymes (AST and ALT).

The interaction between housing system and sex on the haematological and serum parameters of the rabbits in the first generation (Table 8) showed higher significant $(p<0.05)$ difference in two of the parameters namely PCV and WBC. The female rabbits in the cage system recorded the highest PCV and WBC than the males and their counterparts in the deep litter system.
The interaction between housing system and sex on the haematological and serum parameters of the rabbits in second generation is presented in Table 9. Only WBC was significantly $(\mathrm{P}<0.05)$ influenced with male rabbits in the deep litter system recording the higher value of $8.0 \times 10^{9} / \mathrm{L}$ than their female counterparts and those in the cage system. PCV was the same for both sexes in the cage system while in the deep litter system, the female rabbits recorded numerical higher values than the males. Furthermore, male rabbits in the deep litter system recorded the highest values for $\mathrm{Hb}, \mathrm{RBC}$, total protein, albumin, globulin and creatinine while female rabbits in the cage system recorded the highest values of $77.15 \mathrm{mg} / \mathrm{dl}$ and 25.00U/L for glucose and AST respectively. The value of creatinine $(0.95 \mathrm{~g} / \mathrm{dl})$ was the same for both sexes in the cage system.

\section{Discussion}

The results on the haematological parameters measured were within normal range (RAR, 2009). The mean values (4.45 $\left.-8.00 \times 10^{9} / \mathrm{L}\right)$ of $\mathrm{WBC}$ measured were close to the normal physiological range for rabbits as reported by Mitruka and Rawnsley (1977). They reported a WBC range of $5.00-7.51 \times 10^{9} / \mathrm{L}$ for rabbits. The values of $\mathrm{Hb}$ and PCV $(9.73-11.25 \mathrm{~g} / \mathrm{dl}$ and $29.75-33.50 \%$, respectively) reported in this study were also within $(10-17.4 \mathrm{~g} / \mathrm{dl}$ and $33.0-50.0 \%$ ) as reported by Mitruka and Rawnsley (1977) and a range of 9.0$21.3 \mathrm{~g} / \mathrm{dl}$ and $27-57 \%$ of $\mathrm{Hb}$ and $\mathrm{PCV}$, respectively, reported by Bennette and Hawkey (1988).

Packed cell volume (PCV), which is an indicator of blood dilution (Mitruka and Rawnsley, 1977; Wilson and Brigstoke, 1981), red blood cells (RBC) and haemoglobin (HB) were higher (though not 
Table 3: Effect of housing system on the haematology and serum profile of rabbits in second generation

\begin{tabular}{llll}
\hline Parameters & \multicolumn{2}{c}{ System } & SEM \\
\cline { 2 - 3 } & Cage & Deep Litter & 0.89 \\
\hline Packed Cell Volume $(\%)$ & 33.00 & 33.75 & 0.22 \\
Haemoglobin $(\mathrm{g} / \mathrm{dl})$ & 11.15 & 11.35 & 2.93 \\
White Blood Cell $\left(\mathrm{x} 10^{9} / \mathrm{L}\right)$ & 7.61 & 7.20 & 0.14 \\
Red Blood Cell $\left(\times 10^{12} / \mathrm{L}\right)$ & 3.85 & 3.95 & 2.25 \\
Glucose $(\mathrm{mg} / \mathrm{dl})$ & 71.90 & 76.11 & 1.12 \\
Total serum protein $\left(\mathrm{gl}^{-1}\right)$ & $58.38^{\mathrm{b}}$ & $64.28^{\mathrm{a}}$ & 0.70 \\
Albumin $\left(\mathrm{gl}^{-1}\right)$ & $33.02^{\mathrm{b}}$ & $35.05^{\mathrm{a}}$ & 1.05 \\
Globulin $\left(\mathrm{gl}^{-1}\right)$ & $25.35^{\mathrm{b}}$ & $29.23^{\mathrm{a}}$ & 0.09 \\
Creatinine $\left(\mathrm{mgdl}^{-1}\right)$ & 0.95 & 1.03 & 1.12 \\
AST $(\mathrm{U} / \mathrm{L})$ & 22.50 & 24.00 & 1.50 \\
ALT $(\mathrm{U} / \mathrm{L})$ & 15.75 & 15.50 & \\
\hline
\end{tabular}

$\mathrm{a}, \mathrm{b}$ : Means on the same row with different superscripts are significantly different at $(\mathrm{p}<0.05)$

AST- Aspartate amino transferase

ALT- Alanine amino transferase

Table 4: Effect of sex on haematology and serum profile in first generation

\begin{tabular}{|c|c|c|c|}
\hline \multirow[b]{2}{*}{ Parameters } & \multicolumn{2}{|c|}{ Sex } & \multirow[b]{2}{*}{ SEM } \\
\hline & Male & Female & \\
\hline Packed Cell Volume (\%) & 29.75 & 33.00 & 1.83 \\
\hline Haemoglobin $(\mathrm{g} / \mathrm{dl})$ & 9.73 & 11.15 & 0.75 \\
\hline White Blood Cell $\left(\times 10^{9} / \mathrm{L}\right)$ & 5.50 & 5.69 & 3.08 \\
\hline Red Blood Cell $\left(\times 10^{12} / \mathrm{L}\right)$ & 3.75 & 3.68 & 0.26 \\
\hline Glucose $(\mathrm{mg} / \mathrm{dl})$ & 67.68 & 76.30 & 3.79 \\
\hline Total serum protein $\left(\mathrm{gl}^{-1}\right)$ & 59.48 & 57.11 & 1.83 \\
\hline Albumin $\left(\mathrm{gl}^{-1}\right)$ & 38.38 & 37.20 & 1.92 \\
\hline Globulin $\left(\mathrm{gl}^{-1}\right)$ & 21.12 & 19.09 & 2.09 \\
\hline Creatinine $\left(\mathrm{mgdl}^{-1}\right)$ & 0.85 & 0.88 & 0.09 \\
\hline $\operatorname{AST}(\mathrm{U} / \mathrm{L})$ & 14.25 & 19.25 & 1.81 \\
\hline ALT (U/L) & 12.17 & 12.25 & 1.01 \\
\hline
\end{tabular}

AST- Aspartate amino transferase

ALT- Alanine amino transferase 
Table 5: Effect of sex on haematology and serum profile in second generation

\begin{tabular}{|c|c|c|c|}
\hline \multirow[b]{2}{*}{ Parameters } & \multicolumn{2}{|c|}{ Sex } & \multirow[b]{2}{*}{ SEM } \\
\hline & Male & Female & \\
\hline Packed Cell Volume (\%) & 33.25 & 33.50 & 0.89 \\
\hline Haemoglobin $(\mathrm{g} / \mathrm{dl})$ & 11.25 & 11.25 & 0.21 \\
\hline White Blood Cell $\left(\times 10^{9} / \mathrm{L}\right)$ & 7.73 & 7.09 & 3.12 \\
\hline Red Blood Cell $\left(\times 10^{12} / \mathrm{L}\right)$ & $4.12^{\mathrm{a}}$ & $3.68^{\mathrm{b}}$ & 0.10 \\
\hline Glucose $(\mathrm{mg} / \mathrm{dl})$ & $69.23^{\mathrm{b}}$ & $78.78^{\mathrm{a}}$ & 1.78 \\
\hline Total serum protein $\left(\mathrm{gl}^{-1}\right)$ & 60.73 & 61.93 & 1.37 \\
\hline Albumin $\left(\mathrm{gl}^{-1}\right)$ & 34.48 & 33.60 & 0.76 \\
\hline Globulin $\left(\mathrm{gl}^{-1}\right)$ & 26.25 & 28.33 & 1.19 \\
\hline Creatinine $\left(\mathrm{mgdl}^{-1}\right)$ & 1.01 & 0.98 & 0.09 \\
\hline $\operatorname{AST}(\mathrm{U} / \mathrm{L})$ & 22.00 & 24.50 & 1.06 \\
\hline ALT (U/L) & 15.50 & 15.75 & 1.58 \\
\hline
\end{tabular}

$\mathrm{a}, \mathrm{b}$ : Means on the same row with different superscripts are significantly different at $(\mathrm{p}<0.05)$ AST- Aspartate amino transferase

ALT- Alanine amino transferase

Table 6: Interactive effect of generation and housing system on haematology and serum profile of rabbits

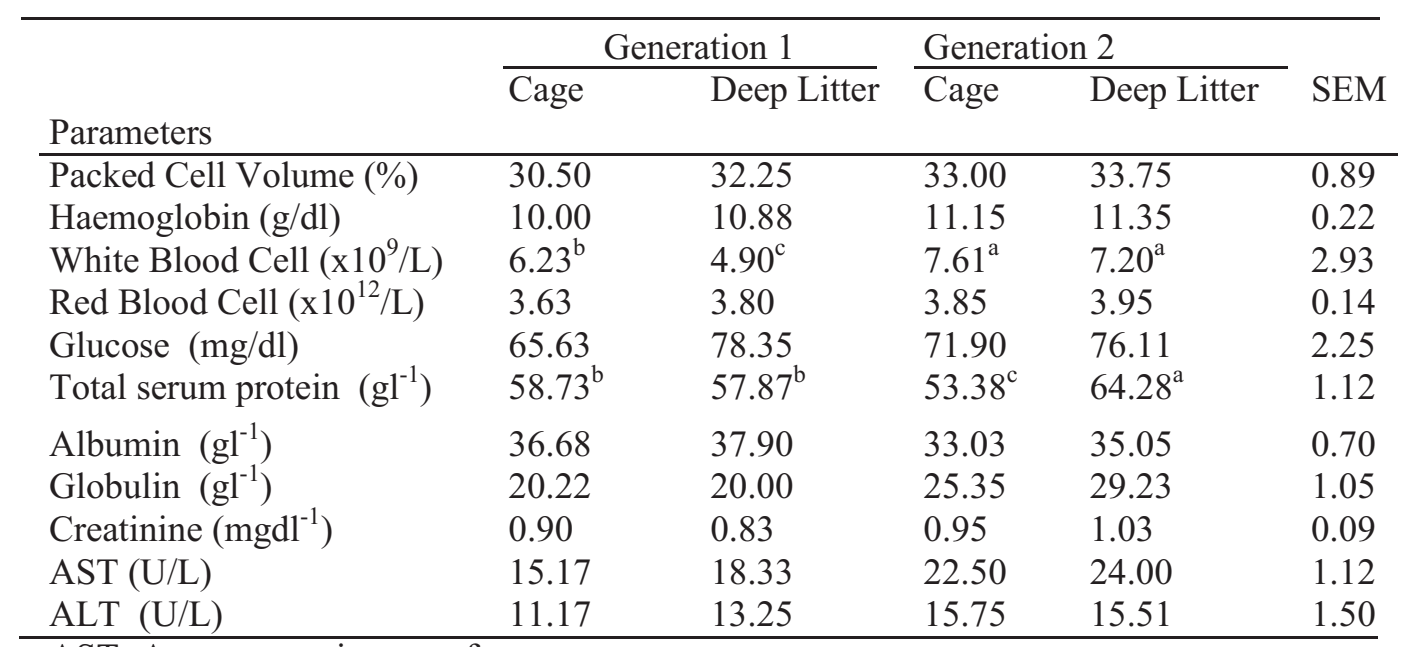

AST- Aspartate amino transferase

ALT- Alanine amino transferase 
Table 7: Effect of generation and sex on haematology and serum profile of rabbits

\begin{tabular}{llllll}
\hline & \multicolumn{2}{c}{ Generation 1 } & \multicolumn{2}{c}{ Generation 2 } \\
Parameters & Male & Female & Male & Female & SEM \\
\hline Packed Cell Volume $(\%)$ & 29.75 & 33.00 & 33.25 & 33.50 & 0.89 \\
Haemoglobin $(\mathrm{g} / \mathrm{dl})$ & 9.73 & 11.15 & 11.25 & 11.25 & 0.21 \\
White Blood Cell $\left(\mathrm{x} 10^{9} / \mathrm{L}\right)$ & 5.50 & 5.69 & 7.73 & 7.09 & 3.12 \\
Red Blood Cell $\left(\times 10^{12} / \mathrm{L}\right)$ & 3.75 & 3.68 & 4.12 & 3.68 & 0.10 \\
Glucose $(\mathrm{mg} / \mathrm{dl})$ & 67.68 & 76.30 & 69.23 & 78.78 & 1.78 \\
Total serum protein $\left(\mathrm{gl}^{-1}\right)$ & 59.48 & 57.11 & 60.73 & 61.93 & 1.37 \\
Albumin $\left(\mathrm{gl}^{-1}\right)$ & 38.38 & 37.20 & 34.48 & 33.60 & 0.76 \\
Glo bulin $\left(\mathrm{gl}^{-1}\right)$ & 21.13 & 19.09 & 26.25 & 28.33 & 1.19 \\
Creatinine $\left(\mathrm{mgdl}^{-1}\right)$ & 0.85 & 0.88 & 1.01 & 0.98 & 0.09 \\
AST $(\mathrm{U} / \mathrm{L})$ & 14.25 & 19.25 & 22.00 & 24.50 & 1.06 \\
ALT $(\mathrm{U} / \mathrm{L})$ & 12.17 & 12.25 & 15.50 & 15.75 & 1.58 \\
\hline
\end{tabular}

AST- Aspartate amino transferase ALT- Alanine amino transferase

Table 8: Interaction effect of housing system and sex on the haematology and serum profile of rabbits in first generation

\begin{tabular}{llllll}
\hline \multirow{2}{*}{ Parameters } & \multicolumn{2}{c}{ Cage } & \multicolumn{2}{c}{ Deep Litter } & \\
\cline { 2 - 5 } & Male & Female & Male & Female & SEM \\
\hline Packed Cell Volume (\%) & $26.50^{\mathrm{c}}$ & $34.50^{\mathrm{a}}$ & $33.00^{\mathrm{ab}}$ & $31.50^{\mathrm{b}}$ & 0.88 \\
Haemoglobin $(\mathrm{g} / \mathrm{dl})$ & 8.30 & 11.70 & 11.15 & 10.60 & 1.26 \\
White Blood Cell $\left(\mathrm{x} 10^{9} / \mathrm{L}\right)$ & $5.65^{\mathrm{b}}$ & $6.93^{\mathrm{a}}$ & $5.35^{\mathrm{b}}$ & $4.45^{\mathrm{c}}$ & 3.60 \\
Red Blood Cell $\left(\mathrm{x} 10^{12} / \mathrm{L}\right)$ & 3.43 & 3.83 & 4.08 & 3.53 & 0.36 \\
Glucose $(\mathrm{mg} / \mathrm{dl})$ & 56.25 & 75.00 & 79.10 & 77.60 & 2.58 \\
Total serum protein $\left(\mathrm{gl}^{-1}\right)$ & 59.25 & 58.20 & 59.72 & 56.02 & 1.91 \\
Albumin $\left(\mathrm{gl}^{-1}\right)$ & 38.60 & 36.75 & 38.15 & 37.65 & 2.33 \\
Globulin $\left(\mathrm{gl}^{-1}\right)$ & 20.65 & 19.78 & 21.60 & 18.40 & 2.47 \\
Creatinine $\left(\mathrm{mgdl}^{-1}\right)$ & 0.91 & 0.90 & 0.80 & 0.85 & 0.13 \\
AST (U/L) & 11.83 & 18.50 & 16.67 & 20.00 & 2.05 \\
ALT (U/L) & 10.83 & 11.50 & 13.50 & 13.00 & 1.21 \\
\hline
\end{tabular}

$\mathrm{a}, \mathrm{b}$ : Means on the same row with different superscripts are significantly different at $(\mathrm{p}<0.05)$ AST- Aspartate amino transferase ALT-Alanine amino transferase 
significant) in the second generation than the first generation. This is an indication that the animals had high oxygen carrying capacity and the ability to withstand stress. The PCV values indicate if the rabbits are anaemic or dehydrated. This implies that the rabbits had good health status in both generations. This supports the finding of Aster (2004) who reported that low PCV value indicates anaemia while high PCV values suggest dehydration.

Higher significant values of white blood cells (WBC) observed in the second generation may be as a result of high or very fast rate of production of WBC population in the bone marrow. The WBC play prominent role in disease resistance especially with respect to the production of antibodies and the process of phygocytosis (Soetan et al., 2013). The WBC mean value obtained from rabbits housed on the deep litter in the first generation was significantly lower than that of rabbits held in the cage but was still within the reported physiological range of $4.50-11.00 \times 10^{9} / \mathrm{L}$ for normal rabbits (RAR, 2009). This result implies that the animal's ability to combat infection or illness was not negatively affected since WBC is known to be among body defense mechanisms that fight against non-self or pathogenic organisms.

Sex showed no significant effect on the biochemical parameters studied except $\mathrm{RBC}$ and glucose in the second generation. Female rabbits had significantly higher glucose and AST values than the males. AST occurs in a wide variety of tissues, but with high concentrations in muscular tissues and in liver (Kaneko 1980; Bush 1991; Dial 1995). The decrease in AST activity in the males could therefore be a reflection of the absence of degenerative changes in their muscles and livers. Laird et al. (1970) earlier reported significant effects of age on some haematological parameters in rabbits as well as significantly higher $\mathrm{Hb}$ and haematocrit values in males. This report is in contrast with the result obtained in this study as lower $\mathrm{Hb}, \mathrm{PCV}$, glucose and AST were observed in the males. The result also revealed that the glucose levels in the blood of the experimental rabbits in both generations were adequate for their proper physiological functions.

The mean values of the serum protein

Table 9: Interaction effect of housing system and sex on the haematology and serum profile of rabbits in second generation

\begin{tabular}{|c|c|c|c|c|c|}
\hline \multirow[b]{2}{*}{ Parameters } & \multicolumn{2}{|c|}{ Cage } & \multicolumn{2}{|c|}{ Deep Litter } & \multirow[b]{2}{*}{ SEM } \\
\hline & Male & Female & Male & Female & \\
\hline Packed Cell Volume (\%) & 33.00 & 33.00 & 33.50 & 34.00 & 1.16 \\
\hline Haemoglobin $(\mathrm{g} / \mathrm{dl})$ & 11.10 & 11.20 & 11.40 & 11.30 & 0.24 \\
\hline White Blood Cell $\left(\times 10^{9} / \mathrm{L}\right)$ & $7.45^{\mathrm{a}}$ & $7.78^{\mathrm{a}}$ & $8.00^{\mathrm{a}}$ & $6.40^{\mathrm{b}}$ & 4.98 \\
\hline Red Blood Cell $\left(\times 10^{12} / \mathrm{L}\right)$ & 4.07 & 3.63 & 4.17 & 3.73 & 0.16 \\
\hline Glucose $(\mathrm{mg} / \mathrm{dl})$ & 66.65 & 77.15 & 71.80 & 80.42 & 2.60 \\
\hline Total serum protein $\left(\mathrm{gl}^{-1}\right)$ & 55.70 & 61.05 & 65.75 & 62.80 & 0.92 \\
\hline Albumin $\left(\mathrm{gl}^{-1}\right)$ & 32.45 & 33.60 & 36.50 & 33.60 & 0.57 \\
\hline Globulin $\left(\mathrm{gl}^{-1}\right)$ & 23.25 & 27.45 & 29.25 & 29.20 & 0.80 \\
\hline Creatinine $\left(\mathrm{mgdl}^{-1}\right)$ & 0.95 & 0.95 & 1.07 & 1.00 & 0.16 \\
\hline $\operatorname{AST}(\mathrm{U} / \mathrm{L})$ & 20.00 & 25.00 & 24.00 & 24.00 & 1.53 \\
\hline $\operatorname{ALT}(\mathrm{U} / \mathrm{L})$ & 16.50 & 15.00 & 14.50 & 16.50 & 1.36 \\
\hline
\end{tabular}

$\mathrm{a}, \mathrm{b}$ : Means on the same row with different superscripts are significantly different at $(\mathrm{p}<0.05)$ AST- Aspartate amino transferase ALT-Alanine amino transferase 
observed were not significantly influenced by sex while housing system had significant effect on some parameters. A similar trend was observed by Patton et al. (1982) and Ganong (1991). Serum protein and albumin synthesis are related to the amount of available protein (Iyayi and Tewe, 1998). The significant increase observed in albumin and globulin in the deep litter system in the second generation might be that the rabbitts were able to utilize the available protein in their feed better in one generation than the other. The increase in the concentration of the two serum transaminases suggests poor utilization of nutrients in the feeds. This could further be explained by the fact that in the case of insufficient energy, the removal of the amino group of the protein to yield corresponding acid which later enters the tricarboxylic acid cycle for addition and energy generation is being promoted (Adeniji and Ogunmodede, 2006).

It is a well established and accepted fact that in serum enzymology, tissue soluble enzymes are a very important adjunct to clinical diagnosis of tissue damage or disease (Harper et al., 1979). Both transaminases in conjunction with other enzymes are used as indicators of liver and heart damage. AST is involved in the interconversion of aspartate to glutamate while alanine transferase is involved in cellular metabolism and energy processes of the cell via the citric acid cycle. This study indicated that both housing systems support rabbit production without any negative influence on the immune status of the rabbit.

\section{Conclusion}

Housing system had significant effect on total soluble protein, albumin and globulin in the deep litter system in the second generation. Sex had no significant effect on the biochemical parameters studied except for RBC, glucose and aspartate amino transferase (AST). Female rabbits had significantly higher glucose and AST values than the males.

\section{References}

Adeniji, C. A. and Ogunmodede, B. K. 2006. Growth, nutrient retention and serum metabolites in broiler chickens fed high hulled sunflower seed cake. Nigerian Journal of Animal Production 33(2): 222-229.

Aderemi, F. A. 2004. Effects of replacement of wheat bran with cassava root sieviate supplemented or unsupplemented with enzyme on the haematology and serum biochemistry of pullet chicks. Trop. J. Animal Sci., 7:147-153.

Aster, J. C. 2004. Anaemia of diminished erythropoiesis. In V. Kumar, A. K. Abbas, N. Fausto, S. L. Robbins, \& R. S. Cotran (Eds.), Robbins and Cotran Pathologic Basis of Disease (7th ed., p.638-649). Saunders Co. Philadelphia.

Bennette, P. M. and Hawkey, C. M. 1988. Comparative haematology phylogenetic and ecological aspects in mammals and birds. The Institute of Zoology, Zoological Society of London Regents Park, London NW14RY.Cambridge University Press. Cambridge, Great Britain 34$37 \mathrm{pp}$.

Bush, B. M., 1991. Interpretation of laboratory results for small animal clinicians. Blackwell Science Publication, London.

Davice, J. U. and Lewis S.M. 1991. Practical haematology.8th Edition. Longman Ltd., London, UK, 22-68.

Dial, S. M., 1995. Clinical pathological 
evaluation of the liver. The Veterinary Clinics of North America 25:257-293.

Duncan, D. B. 1955. Multiple range and multiple F-test. Biom. 14: 1-42.

Ewuola, E. O., Folayan, O. A., Gbore, F. A., Adebunmi, A. I., Akanji, R. A., Ogunlade, J. T. and Adeneye, J. A. 2004. Physiological response of growing West African Dwarf goats fed groundnut shell-based diets as the concentrate supplements. BOWEN J. Agric. 1(1):61-69.

Ganong, W.F., 1991. Review of medical physiology, $15^{\text {th }}$ Ed., Appleton and Large, Connecticut.

Google Earth, 2006. Google location map; Google earth imagery date; December $3^{\text {rd }}, 2006$.

Harper, A. E., Rodwell and Mayes, P. A. 1979. Review of physiological Chemistry. $17^{\text {th }}$ ed. Lang Medical, Los Altos, California 9442, 60(81): 188216.

Iyayi, E. and Tewe, O. 1998. Serum total protein, urea and creatinine levels as indices of quality of cassava diets for pigs. Trop. Vet. 16: 59-67.

Kaneko, J. J., 1980. Clinical biochemistry of domestic animals. 3rd Edn. Academic Press Inc., New York.

Laird, C.W., Fox, R. R, Mitchell, B. P., Blau, E. M. and Schutlz H.S. 1970. Effects of strain and age on some haematological parameters in the rabbit. Amer. J. Physiol. 218: $1613-$ 1617.

Mitruka, B. M. and Rawnsley, H. M. 1977. Clinical, biochemical and haematological reference values in normal experimental animals. Masson Pub. Inc., New York, pp: 21-84.

Patton, N. M., Aris, D. J., Grobner, N.A., Swick, R.A. and Cheeke P. R. 1982. Effect of dietary copper sulphate on enteritis in frier rabbit. J. of Appl. Res., 5: 78-82.

Research Animal Resource (RAR). 2009. Reference values for laboratory animals: Normal haematological values. RAR Websites, RAR, University of Minnesota.Retrieved fromhttp://www.ahc.umn.edu/rar/ref values.html.

SAS, 1999. SAS User's Guide Statistical Analysis Institute Inc. Cary. North Carolina

Soetan, K. O., Akinrinde, A. S., and Ajibade, T. O. 2013. Preliminary studies on the haematological parameters of cockerels fed raw and processed guinea corn (Sorghum bicolor) (p. 49-52). Proceedings of 38th Annual Conference of Nigerian Society for Animal Production.

Wilson, W. D. and Brigstoke, E. E. 1981. The haematology of living tissues. Mc. Hill Publishing Company. Pp 101-172.

Received: $6^{\text {th }}$ July, 2014 Accepted: $12^{\text {th }}$ February, 2015 